\title{
General population and HIV prevention: from risk to action
}

\author{
População geral e prevenção da infecção \\ pelo HIV: do risco para a ação
}

Genevi ève Paicheler 1

\footnotetext{
1 Centre de Recherche Médecine, Maladie et Sciences Sociales (CERMES), Centre National de Ia Recherche ScientifiqueCERMES,182,boulevard de la Villette,75019, Paris, France. paichele@ext.jussieu.fr
}

\begin{abstract}
Since knowledge about AIDS transmission now appears to be very good, many observers are surprised that more people do not practice behavior, like safer sex, designed to minimize risk of contracting the disease. Still, previ ous stu dies have not shown that there is a di rect link betwen knowledgeand behavior. New models, based on people's concrete experiences,are therefore needed. The goal of thisqualitative research, based on 61 in-depth interviews conducted in France, is to describehow people understand thethreat of AIDS and how they face the risk of transmission in their sex lives. In order to understand preventive actions, we must study how information is interpreted and how knowledge is integrated, so that peoplepercei ve general or personal risk. Wemust also specify the way in which people distinguish between aspects of risk perception and vulnerability; feelings of personal control, constructed on thebasis of social experiences;characteristics of situations; and finally, the dynamics of action. The proposed risk management model accountsfor these diverse factors in elucidating the great diversity of actions reported. This dynamic, non-linear model is designed to capture both the impact of perceptive and cognitive el ements on action and vice versa. Key words Heal th Education; HIV; Acqui red Immunodeficiency Syndrome; Sex Behavior; Risk
\end{abstract}

Resumo Uma vez que o conhecimento sobre a transmi ssão da AIDS parece ser excelente, diversos observadores se surpreendem ao constatar que mui tos indi víduos não têm comportamentos vol tados para a redução do risco de contrair a doença, como sexo seguro. Mesmo assim, estudos anteriores dei xaram de demonstrar um elo di reto entre conheci mento e comportamento. Portanto, são necessários novos modelos, baseados na experiência concreta das pessoas. O objetivo desta pesquisa qual itati va, baseada em 61 entrevi stas detal hadas conduzi das na França, é descrever como os indi ví duos percebem a ameaça da AIDS e como lidam com o risco da transmissão desta dentro das suas vi das sexuais. Para poder entender as diversas medi das preventivas, temos que investigar como a informação éi nterpretada e como o conhecimento éintegrado, a fim de queas pessoas percebam o risco geral ou pessoal. Devemos especificar, também, a maneira pela qual as pessoas fazem a distinção entre aspectos de percepção de risco e de vulnerabilidade; sentimentos de control e pessoal, construí dos com base em experiências sociais; característi cas de situações e, finalmente, a dinâmica da ação. O modelo proposto para lidar com o risco leva em conta esses diversos fatores na elucidação da grande di versi dade de medi das relatadas. Esse modelo dinâmi co, não linear, é projetado para captar o impacto dos elementos perceptivos e cognitivos sobre a ação, e vi ce-versa. Palavras-chave Educação em Saúde; HIV; Síndrome da Imunodefi ciência Adquirida; Comportamento Sexual; Risco 


\section{Introduction}

The fear that AIDS inspires does not directly lead to preventive behavior. It seems that people have good knowledge about how the virus spreads but numerous KABP (knowledge, attitudes, beliefs, and practices) studies have established no direct link between information and action (Peruga \& Celentano, 1993). These studies were largely inspired by the Health $\mathrm{Be}$ lief Model (Rosenstock, 1974), which establishes a direct and rational connection between knowledge and practice when an individual feels truly concerned by a health threat. This model has been widely criticized (O'Brien, 1989; Fee \& Krieger, 1993; Bloor, 1995a, 1995b) and alternative models have been proposed. For example, the theory of reasoned action integrates social norms and pressures and makes a distinction between intention and action (Fishbein \& Ajzen, 1975). However, this theory remains a model of individual decision-making and proves to be a poor predictor of healthrelated behavior. In order to overcome the deficiencies in these models and find adequate explanations for the changes in behavior that are observed, we must adapt a new frame of reference. Instead of trying to impose preconceived models onto knowledge and practice, a phenomenological approach, which studies how people integrate the threat of AIDS and what they actually do about it, should be adopted.

The emergence of an epidemic and lethal illness raises the question of meaning and understanding. The public has to do more than simply assimilate necessary and sufficient information in order to practice appropriate preventive behavior. Confronted with uncertainty and a plethora of information from diverse sources, laypersons engage in intense activity of sorting and interpretation, as they are forced to situate themselves in terms of the danger (Warwick et al., 1988). Perceiving risk at a societal level does not necessarily imply perceiving risk to oneself, although risk management does depend on modalities of individual risk perception, and also, of course, on the objective margin of action allowed by concrete situations.

Risk is a modern way of understanding pathological danger as an omnipresent and invasive sanitary threat to both populations and individuals (Armstrong, 1993). However, it does not provide a clearer view of the danger involved nor a precise evaluation of it (Douglas \& Wildavsky, 1982). A polysemous and contradictory notion (Hayes, 1992), it designates both external factors, over which no control is possi- ble and conditions considered under the control of individuals, such as pathogenic lifestyles. Furthermore, the concept of risk implies a process that obeys laws based on long series of observations, from which it is paradoxically possible to individually isolate oneself.

It has become very common to use the expression "risky behavior" in the domain of health to refer to the potential control that individuals could have over their health (Jeffery, 1989). According to this logic, some people, while perfectly conscious of the consequences of their action, disregard the sanitary threat and voluntarily put themselves in a situation that threatens their health. "Self-control is therefore a prerequisite for health. Lack of self control, of which detectable symptoms include forms of behavioral, psychological and cognitive organization, is consequently an 'illness' preceding the physical ailment" (Greco, 1993: 161). If people get ill, it is considered to be through weakness or choice. Yet, to choose, one must have a clear and objective vision of the alternatives and consequences associated with the decisions involved. This implies shifting from the domain of "risky behavior" to "risk perception". To really be responsible, does one not have to be capable of evaluating danger with full knowledge of its origin so as to be able to make the most judicious choices possible? Can we expect a reliable evaluation from epidemiologists? Probably not, since they, like all researchers, have a specific view of the phenomenon and choose among the limited amount of information that can be gathered and processed. Epidemiological studies function more as a normalizing technique. "Therationalized mathematical logic and rhetoric of the discourse of epidemi ology serves to obscure moral judgments about individuals' or groups' behavior" (Lupton, 1995:67).

Studies of risk-taking note the difficulty involved in assessing the probabilities of events and the consequences of action. The notion of risk is always linked to decision-making in a situation of uncertainty (O'Brien, 1989). Yet decision-making is simultaneously conceptualized as an individual and voluntary act. In the field of social science of risk, individualistic paradigms dominate, al though they are criticized. In contrast, Douglas (1992) situates the problematic of risk in a cultural perspective. For her, risk is a modern way of contemplating danger by evaluating it in terms of probability, in a context of uncertainty. Risk (or danger) is not an absolute given, but is moralized and politicized through a process of selection and social construction. Are our societies' methods 
of reason or calculation of risk any more rational than relying on chance, mystery, or malevolence? Science does not contribute to the identification of more concrete threats, the isolation of real dangers, whose causes are objectively identified, guaranteed by the authority of experiments and theory (Douglas \& Wildavsky, 1982). Apparent scientific objectivity does not allow us to escape the fact that, in any society: "risk-taking and risk aversion, shared confidence and shared fears, are part of the dialogue on how to best organizesocial relations" (Douglas \& Wildavsky, 1982:8).

The individual istic vision of risk has been the object of numerous critiques (Bloor et al., 1992). This positivistic vision misinterprets the social, cultural, moral, and political dimension of risk, especially as it relates to health (Lupton, 1993; Gabe, 1995). It assumes that if individuals or scientific evaluators do not have access to the truth about given risks, it is because the instruments of evaluation are flawed. Rational and cal culated perception is still considered possible. Yet, all probabilistic evaluations of events are made in a context of uncertainty, a condition which certain individual s tolerate and manage better than others. These evaluations lend themselves to different simplifications and translations. Percentages are translated into ordinal measures and discrete categories, which are simplified and easier to conceptualize and act upon (Parsons \& Atkinson, 1992). For laypersons, risk can only be integrated if it is translated into the terms of subjective, lived experience. It is impossible to require them to view themselves and the events that affect them with the detached perspective of a demographic statistician.

Risk is only one angle of a prism that allows people to understand the problematic of AIDS. The construction of lay knowledge of this illness operates on different registers that coexist with a certain independence, even contradiction. Globally, it is possible to distinguish between two levels of socio-cognitive processes: the representations of illness or of ill people and the perception of risk (Paicheler, 1994). The level of representations does not seem to be specific to AIDS. Rather, we find, in discussion of this illness, metaphors that characterize all illnesses, or all serious illnesses, as they have been described for decades (Herzlich, 1969; Sontag, 1978). Perception of risk is developed according to three registers of variable forms of perceived vulnerability - catastrophe, social vulnerability, and corporal vulnerability - and has a clear impact on preventive actions.
In order to understand how people develop AIDS preventive actions, several plans of investigation must be articulated:

- consider which information, from among that which is diffused - including information aimed at prevention - is most likely to influence action;

- account for processes of interpretation and integration of knowledge both on an individual and collective level;

- demonstrate how these processes all ow for the elaboration of general and personal risk perception;

- in analyzing action, distinguish between elements related to risk perception and feelings of vulnerability, sense of personal control based on social experience, characteristics of the situation, and finally, actual dynamics of action.

This article will focus on the last two aspects.

\section{Methods}

Sixty-one in-depth interviews of approximately one and a half hours were conducted. The initial instructions asked respondents: "Can you tell me what the word "AIDS" evokes for you?" This type of interview methodology provides individuals a certain latitude of expression so that they have the opportunity to theorize more or less naively - about their own experiences and conceptions. This allows them space in which to elaborate a discourse that, under other conditions, would probably not have the opportunity to emerge in the same terms. The interviewer focuses on the respondents' words and styles of reasoning, strictly follows the structure of the argument, and helps the respondents express themselves and make sense of their reasoning and actions. In this way, the interview is conceptualized as an act of discourse in which two interlocutors jointly construct meaning in their interaction (Mishler, 1986).

Since this method implies a limited sample size, the goal is obviously not representativeness but diversity in terms of specific variables that bear upon the problematic at hand. The diversity of the sample accounts for the following variables:

- Gender: 30 men, 31 women.

- Age: three groups concentrated around 20, 30 , and 40 years of age $(\mathrm{N}=20,21$, and 20 , respectively.

- socio-cultural and professional level (upper class, $\mathrm{N}=19$; middle class, $\mathrm{N}=20$; working class, $\mathrm{N}=22$ ). Paris and surrounding suburbs (where rates of HIV are the highest), $\mathrm{N}=37$; 
cities outside of Paris divided into two regions of different epidemiological prevalence and profiles, $\mathrm{N}=24$.

- family status: marriage, divorce, cohabitation, stable or unstable relationship, presence or absence of children, age of children.

With two exceptions (one gay man and one bisexual man), the people interviewed presented themselves as heterosexuals.

The interviews were analyzed on a thematic (synchronic) level, and according to the logic of the argumentation. An automatic lexical analysis was conducted using two programs: ALCESTE and HYPERBASE. A diachronic analysis of actions reported and their determinants was performed for each interview.

\section{Findings}

I) Perceiving Risk

\section{- Risk Perception Obstacles}

In order to evaluate risk, people use diverse resources, including access to information, observation, and experience. Yet availability of information is imperfect, either because certain information does not exist, it does not circulate outside of a small circle of specialists, or because it is tainted with uncertainty. In addition, observation and experience are grounded in inevitably partial and biased perspectives. Among the general population today in France, the majority of individuals have not had the opportunity to personally know someone with HIV. There were 45,204 cumulated cases of AIDS on September 30, 1996, and approximateIy 120,000 HIV-positive people, out of some 60 million residents (HIV/Aids Surveillance in Europe, 1996). Yet such an experience serves to greatly increase people's sense of risk, leading some to overestimate it, even though it does not preclude people's tendencies to distance themselves from it. If we add to these considerations the fact that systematic deviations are produced by "heuristics" that allow for risk comprehension, especially concerning representativeness and availability (Tversky \& Kahneman, 1974), we see that a correct theoretic evaluation is very improbable. In addition, "chance is commonly viewed as a self-correcting processin which a deviation in one di rection induces a deviation in theopposi tedirection to restore the equilibrium" (Tversky \& Kahneman, 1974:1125). People are thus amazed by chance surprises like contamination during the first sexual relation with someone who is HIV-posi- tive or, the opposite: absence of infection after a long history of contact. "Imagine that I sleep with someone who has AIDS. I don't know if I'll systematically be HIV-positive after one act" (since there are few citations from the interviews and they were chosen for their exemplary character, they are presented anonymously, in italics). "We've seen women who had gotten AIDS in one way or another, who lived with their husbands, who had normal sex lives, and the husbands never got it." In addition, as with the consumption of tobacco or alcohol, the consequences connected to each event seem less probable because they are separated in time. "It's a bit like when someone tells you: 'you smoke,you're going to get cancer in twenty, thirty or forty years,' it's so far off..."

But even if the prevalence rate in France is one of the highest in Europe, AIDS remains an unreal, far-off threat. Not having accessible examples of infection makes it very abstract. “There's a lot of talk about AIDS, but since we don't know many peoplearound uswho haveit, we say: 'that won't happen to me, and, she's twenty years old, she's like me, why would she have AIDS?'. 'Not knowing people who havethe illness or who are HIV-positive,it's not real ,it's very abstract, an artistic blur..."“

Knowing someone who is infected allows one to realize the presence of risk for oneself. Yet, this does not always eliminate contradictions: "Weare all at risk," said a woman interviewed, despite an earlier remark: "I know that women haveit. Among the peoplel know, only men haveit and it's truethat, for them, it's connected to their homosexual activity. Now it's a horror that can also touch me"

Since risk is expressed in terms of probabilities, certain people think that knowledge of rates of infection or epidemiological data are necessary for a good evaluation of risk. Yet these seem to be either indecisive or distorted. People are particularly suspicious of information circulated by the media, especially in the lower class (Paicheler \& Quemin, 1994a). "They talk to us about AIDS, about the danger, but we don't know what we should do, besides protect ourselves, of course. What is the proportion of drug addicts who haveAIDS? Who are the people who are most affected? Which ages? Teens? We'd like more details and percentages so as to know which people are most likely to have it..."

People are struck by controversies over epidemiological evaluation. Difficulties in estimating the number of people infected fosters doubt. Even though those who produce the figures consider them to represent neutral and objective knowledge, they are not perceived as 
such. Computational problems seem to be full of meaning and continually pushed aside. "They say that they want to tell us, yet we livein a country where informati on ci rculates a priori... They tell me that thereare 300,000 people with AIDS, but maybe there are actually only $100,000 . .$. It's possiblethat there are one million and they don't want us to panic or that thereare 100,000 and they want us to be careful." For some, the press and the government contribute to the circulation of false figures. The proof that they are false lies in the lack of coherence. "We should try to get some real statistics, some real data, sometruefigures. Maybetheones they give us are true, but I doubt it because one day they give us one figure, the next another, so we never know exactly where we are."

It remains very difficult for most to evaluate personal risk through a probabilistic logic. This is either because people do not think that they have enough or reliable enough information; because none of their acquaintances are experiencing the threat first-hand, which would make it seem more concrete; or because rules about large numbers have little use for managing everyday life.

Perception of personal risk is elaborated less according to statistical data than in terms of one's own feelings of vulnerability and the possibility of protection from danger. Douglas \& Calvez's (1990) analysis distinguishes two forms of individual protection: "corporal envelope" and "social envelope". A third register should be added to this analysis, that of the catastrophe, when protection becomes impossible.

- Catastrophe and the impossibility of protection

In this first register, danger is dramatized, especially in the lower class where the availability of information is reduced. The risk of AIDS is frequently presented, notably in the mass media, and perceived as a catastrophe: a tidal wave that progresses rapidly and reaches "everyone" without discrimination or any particular reason. "It's morethan an illness, it's a fatal ity, it's like a plague from Egypt that has fallen out of the sky... All of a sudden, it's an incrediblesword of Damocles, that makes the possibility of dying pressing again, without any sol ution or answer." This discourse evokes the arbitrary, the uncontrollable, and blind luck. It is clear that the catastrophe register blocks rational understanding of the illness. "Thisillness, it's like a lottery, because it can happen to anyone... It's like a wheel of fortune or misfortune."
Discourses developed according to the catastrophe register draw on narratives that are deployed in two domains: catastrophe-scenarios and rumors. These stories serve to interpret events by constructing a causal pattern, temporal sequences, by providing images when abstract references are lacking, and by producing feeling and emotions (Sarbin, 1986; Polkinhorne, 1988).

- Catastrophe-scenarios, of which there are multiple versions, show, in an ambiguous way, that it is possible for a chain of highly improbable events to lead to an infection. They are usually constructed according to the same model: the inevitable reception of infected blood from another unknown contaminating person. "I magine I have AIDS and I scratch myself, in fact, I'm bl eeding. I enjoy a drink, getting it all over theglass and the guy behind thebar comes to pick up the glasses. He himself just cut himself cutting lemon to put in Perrier drinks. He takes the glass and he gets it [the virus]." These images confirm that AIDS strikes in a blind and unpredictable way.

- Rumors are a way of explaining elements of the illness' apparition that are not accounted for by approved facts (Paicheler \& Quemin, 1994b). They seek to establish the causes and those "responsible" for the genesis of the illness. They are usually informed by integrated norms, especially in France, about tolerance and non-discrimination, central themes in media campaigns. There are two kinds of rumors:

- People transform verified information into rumors, demonstrating a social hyper-vigilance. The fact that certain groups, namely gays, were designated, is considered indicative of a labeling process that must be denounced and rejected. This designation of "falsely accused" is believed to mask those who are really responsible. "I think that people tried to blame the Blacks because they were black, homosexuals because they were homosexual... Drug addicts also, because, of course drug addicts are mean... I believe that people wanted to discredit these groups."

- Other kinds of rumors draw on erroneous information. They attribute AIDS to blunders of science that are unfortunate because they transform the natural order, or to voluntary and destructive action like biological warfare. This is a way of drawing from a repertoire of people plausibly responsible for the diffusion of the illness: Americans, Nazis, industry, etc. "I think that it's something that was created, maybe by researchers, sci entists, savants; who injected something into a monkey, and afterwards, the monkey got away... Or, they did it on 
purpose, that's even deeper. But, I 'd rather not think about that because it's crazy." Rumors, which rely more on conjecture than certainty, are characterized by a cumulative discourse that tolerates contradiction. All possible hypotheses are imagined and retained, and conviction gathers strength from the social reality of a discourse that reinforces itself as it circulates.

These two types of narration, catastrophescenarios and rumors, are important for understanding phenomena of interpretation. "Telling stories" is a way of elaborating reasons for actions, inferring and resolving problems, revealing cause and effect, creating images for affronting arbitrary and opaque meanings, producing dramatic feelings and emotions, basically forcing oneself to understand.

\section{- Porous bodies and individual vulnerability}

The evocation of bodily fluids - blood, saliva, sperm, or vaginal fluids - occurs in an emotionally and symbolically charged language (Rozin \& Fallon, 1987). This intervention of the symbolic places the discourse of the body and bodily products in a social dimension. Simultaneously, these discourses reflect the domain of beliefs and the fundamental ambiguity between doubt and uncertainty that they express. The expression of the symbolic is never neutral. It evokes strong images, feelings, and commitments. The evocation of bodily fluids can not operate independently of a vision of the world, of systems of prescribed behavior and interdictions, or foundations of a social and corporal identity, nor can it function separately from the powerful emotions associated with it.

The bodily products with which the means of transmission are associated are at the heart of notions of pollution and purity and their corresponding moral orders (Douglas, 1967; Rozin et al., 1992). These notions engender classifications that are at the center of world visions. “...(Pollution powers) punish a symbolic breaking of that which is not likel y to occur except wherethe lines of structure, cosmic or social, are clearly defined (...) A polluting person is al ways in the wrong. He has developed some wrong condition or simply crossed some line which should not have been crossed and this displacement unleashes danger for someone else" (Douglas, 1967/ 1996:136). Discourse on bodily fluids is also a discourse about the world and natural order where danger arises when things are not in their place.

The notion of pollution is connected with a global vision of contagion that applies to more than just illness. It concerns all kinds of contacts with other people, substances, or objects. It assumes that emanation disengages from the body and can act at a distance. In this way, all contact is potentially dangerous but some, such as those connected to bodily 'entry routes', more than others. "We should expect the orifices of the body to symbolizeits specially vulnerable points. Matter issuing from them... by simply issuing forth (has) traversed the boundary of the body" (Douglas, 1996:145).

Discourse about transmission, which evokes the possible implication of different fluid and bodily vectors (blood, sperm, vaginal fluids, saliva), is fundamentally a discourse about the "bodily envelope", the porosity and vulnerability of the body. It is articulated around the following central question: how could the virus penetrate my body? It is therefore necessary to identify both the "vectors" and the "entry routes". It is well known that there are two principal vectors (sexual and blood-related) but the sexual transmission is poorly understood. Just as people have difficulty associating sexual relations with danger, it is difficult for them to imagine how the virus could be passed from one sexual partner to another, notably from women to men. "I totally know that it is sexually transmitted, but I can't imagine how it happens." The translation from abstract vectors to concrete and practical reality is not an easy operation.

Blood - more specifically cuts and bleeding - allows the most logical articulation between situations and infection vectors. Blood is central in representations of transmission. The rate of words related to this fluid (blood) is 835 , compared to the rate of the word saliva $(\mathrm{N}=133)$ and sperm ( $\mathrm{N}=130)$. "Among the methods of transmission, the royal path is blood, if the virus can makeit directly into the blood. That's where the it must be." People search for a logical connection between the different methods of infection, and apparently the logical connection is blood. Sexual transmission is in this way often reduced to the modality of blood-related transmission. Blood that leaves the body and foreign blood that enters are readily perceived as threats. Contact with blood - from cuts and bleeding - allows for the most logical connection between situations and infection vectors. In addition, mixing corporal fluids (blood, saliva, sperm) unleashes the danger of each vector. People question the circumstances, including sexual practices, that allow for such mixing and are a source of disorder and pathology. The fragile parts of the body, or the "entry routes", include orifices, cuts, mucous membranes, those zones that are neither interior 
nor exterior. "Every kind of cut, anything open, is a danger."

Popular reasoning amplifies scientific incertitude. Certain notions that are elaborated in a researcher's office are easily not transposed in popular wisdom. This is particularly the case for the notion of "theoretical risk" involving transmission through saliva. An interview citation expresses well the ambiguity that characterizes the discourse surrounding saliva: “Apparently, it is not transmitted through saliva. Apparently that's certain." In situations of uncertainty concerning the question of transmission, people prefer to take a side. Ultimately, the decision is based on beliefs that profoundly inform everyday life. "I want to think that be cause I prefer to believe in that. If it's not true, if transmission can occur through saliva or sweat, humanity is doomed."

- Threat to groups and social vulnerability

Protection by virtue of belonging to a particular social group is sometimes characterized by a structured and valued community identity and, most often, by a "counter-identity"in which people attribute characteristics and actions to themselves that exclude them from groups "concerned" by AIDS. When community cohesion is weak and therefore contributes little or nothing to structuring identity or guiding action, it is not perceived as protective. Because of this, social protection is often limited to the family or close friends.

Perception of risk here is grounded in social identities, associated with social categories whose vulnerability is obvious because those within them are perceived as living outside of or even transgressing norms (Crawford, 1994; Schiller et al., 1994). Epidemiological discourses about "risk groups" reappear here in an obviously contradictory form since people simultaneously adhere to the norm that "AIDS concerns everyone". "AIDS started in America: it wasj ust gays who got it. It didn't scare people; it only touched one category of people. Afterwards, they say it was the drug addicts with syringes. And then, now, I know that it can strike other people,even though the only peoplethat I know who haveAIDS around meare homosexuals or drugaddicts."

Conformity is experienced as protective and deviance as exposure to danger. To be and behave "like everyone else" is contrasted with identities and actions of particular groups. "Right now, if you behave normally, even if you are in the presence of someone who is HIV-positive, I don't seehow you can haveit." Restricting
AIDS to particular groups allows people to further reassure themselves that these groups are closed off, which is more the case for gays than for users of injectable drugs. Thus, the image of the bisexual crystallizes indiscernible danger. "A single homosexual, who takes risks, who takes no precautions, he knows what he's doing, but heonly involveshimself and his partner. But I really think that guys who are bi sexual, who have wives and kids, are awful." Blurred categories, fuzzy boundaries, overstepped limits, both in terms of identity and social body: threat emerges when the world order is shaken.

\section{II) Managing Risk}

\section{- Aspects of risk management}

Managing the risk of sexual transmission of AIDS varies depending on whether one is male or female, young or old, and whether one lives in a financially and professionally stable world or one in which precariousness is an omnipresent threat. Actions reported during the interviews form a very composite palette. Several factors converge to contribute to particular configurations at any given moment. These include: representations of the body; identity; feelings of vulnerability, security, or efficacy; position in a sexual trajectory; risk perception; subjective distance from the illness; ethical orientations, etc. Knowledge probably also intervenes, but indirectly. On the other hand, the connection between risk perception and behavior seems much clearer (Paicheler, 1996).

Individual and interactive strategies combine to compose a complex collection of risk management methods. On the one hand, the diversity of actions depends on risk perception and the constraints and resources of the situation. On the other hand, the feeling of security ultimately provided by these strategies can be linked to knowledge, but it is also associated with a vision of the world and of oneself and with a conception of one's self efficacy (Bandura, 1992).

Types of risk management can be differentiated into three categories: preventive, focusing on condom use and necessarily interactive; protective, prioritizing individual forms of risk management like abstinence, waiting, selection of partners; or mixed, combining condom use with other forms of protection depending on the situations and interactive capacities.

Whatever actions are used to shield oneself from danger, people can derive a sense of security from the belief that their actions are sufficient and efficient, or they can decide that these do not allow them to control the risk. 
This feeling of security does not only depend on the actions performed. It is also associated with their risk perception, which is informed by feelings of personal or social vulnerability, in turn linked to earlier experiences. This perception conditions whether one feels one is controlling the risk. Still, actions are not only dependent on perceptions, but are also subordinated to the constraints and resources that characterize the specific situations in which they take place. Feelings of security, which can effect vulnerability and risk management, vary in strength depending on the intensity of the perception of risk and the possibilities that a given action will be more or less adequate. The components of risk management form a dynamic system in which all of the elements are in constant interaction (see Figure 1).

\section{- Examples of ways to manage risk}

Five exemplary cases will be presented here. The first consists of a rational way of using a condom, informed by a balanced perception of risk. Two other cases demonstrate condom use that, while systematic, is non-rational, either because it is situated in a context of dramatization or because social vulnerability is exaggerated. In the fourth case, people dispense with using condoms because they feel secure within their social circle. Finally, the dominated and dependent case, which is characteristic of women, illustrates that prevention negotiation is not always possible.

\section{- Control, efficacy, security}

When preventive actions prioritize systematic condom use, they should create a feeling of security and mastery allowing for the dissipation of anxiety. This is emblematic of the rational approach envisioned in prevention campaigns, characterized by a measured and reasonable control of risk. The feeling of vulnerability is moderated and condom use is considered to be both simple and sure. It allows one to both deal with risk and continue to have a diversified sexuality, in which all kinds of sexual rela-

Figure 1

Components of risk management.

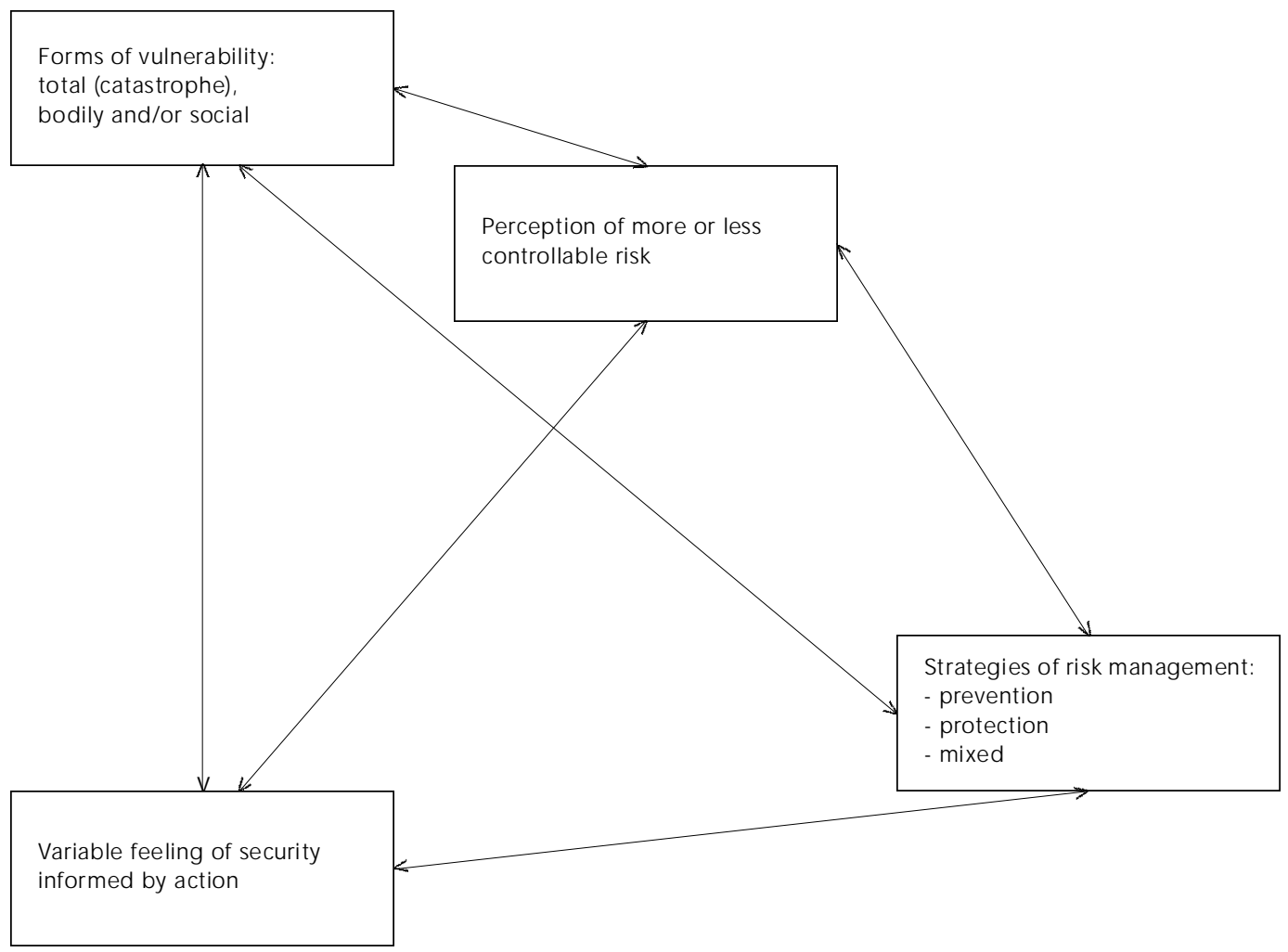


tions can be envisioned without having to ask whether or not one's partner is HIV-positive. We should stress that this kind of tranquil rationality is quite rare.

Sarah, a 20-year-old, middle-class college student, praises the reaction to the threat of AIDS, even though she says she has no idea how AIDS is sexually transmitted: "The only thing to do right now is to be careful, to use a condom," in that the group with which she identifies, young people, date a lot of people and frequently change partners. Unlike blood transfusions, which are impossible to control, people "choose" whether or not to take risks in sexual relations. However, she deplores the necessity of having to negotiate, sometimes firmly, the use of condoms with "boys" who are "incapable of taking it out of their pocket." This gives her the impression of being "forced to fight all of the time." Condoms favor shared responsibility and exchange because it takes two to use them, and usage allows one to accept one's partner even if he/sheis infected. In this way, Sarah is an example of reasoned prevention as specified in media campaigns. However, her determination is not infallible. Like other regular condomusers, she admits that she sometimes "Iet's herself go," wanting to "forget about AIDS,": "sometimes there are lapses." While her risk management strategy is consistent with the concept, praised by the mass media, of safer sex, her "lapses" demonstrate well the limits of this form of risk management and the associated feeling of security. This feeling can lead to risk distancing. Comparable findings emerge in the homosexual population practicing safer sex (Schiltz \& Adam, 1995)

\section{- Dramatizing the risk and reinforced security}

Systematic condom use does not always mitigate the uncertainty connected to the vision of AIDS as an excessive and uncontrollable disease. All forms of protection prove as insufficient as bodily and/ or social "envelopes" seem fragile. Distrust towards all potential partners is great. Condoms are used but this does not lessen the fear of initiating contact with HIV-positive people. Persons in unstable and frail situations show this dramatization, like Muriel, a 32year-old copywriter, who has just gone through breaking off a long and stable relationship.

She uses a discourse tainted with catastrophe because "no one is shel tered" and it's "a bit like a lottery," a "Russian roulette." She lives in a milieu where several people have the virus, people of her age, exclusively men, all homo- sexual. She complains about the uncertainty of available facts: "There's al ways something that's not clear, even in the pharmacy pamphlets. You read them and say in the end: you should just stop having sex entirely." The illness causes "psychoses." "There will al ways be porous rubbers that let things through," so that one of her friends told her that it's better to use two condoms, one on top of the other, a prospect that strikes her as intolerable. When reflecting on the risk linked to sexual practices other than penetration, she wonders if it is necessary to "put rubbers on your tongue to kiss" and concludes that "we can't be sure of anything anymore." In any case, she refuses to use a condom during fellatio and wonders if she is not taking a risk in so doing. In addition to cumulating protective behavior, she performs frequent medical tests for a greater sense of security. The example of Muriel demonstrates how condoms can protect without necessarily providing a feeling of security.

\section{- Protection in an uncertain world}

Condom use can be considered constitutive of taking initiative in an uncertain world, in which it is foolish to believe and have confidence in others. One can only count on oneself in facing this dangerous world. This position appears to be characteristic mostly of the working class. Using a condom is thus presented as an absolute imperative to which no exceptions are possible, but this does not mean that one feels sufficiently protected. Living in an uncertain world produces, as Hoggart (1957) describes, a habitus in which people create islands of control and small stretches of liberty, in a world dominated by other people and outside circumstances. This life seems risky enough already so that one does not take additional risks unnecessarily.

Rodolph, an unemployed 19-year-old, exemplifies this strategy of risk adaptation. His world is filled with danger, of which AIDS is onIy one incarnation of everyday misery. He has to count primarily on himself to use whatever measure of control he can, even relative, over the course of events. Using a condom is an "obligation" to which no exception is tolerated. He has set himself a rule of always using a condom and would not want to take the risk of believing a girl who tells him that she is a virgin or HIV-negative. He would also put on a condom without telling her if she disagreed. To him, the absence of a condom would signify almost certain transmission, even though he knows that this is not the general rule. His rea- 
soning precedes as follows: faced with an eventuality that is serious and costly, he opts for the behavior that assures the most security possible. In the event that he did not have a condom, he would go without the sexual intercourse. "That's what's scary, dying because of that, for a stupi d mistake, because one day you didn't put on a condom." Still, life is rough in "a rotten world." Condoms protect, but not from everything. They are not infallible. Even when he sleeps with a girl with a condom, he still has "a slight regret": “I hope that there isn't a hole, that the rubber hasn't torn." When the sentiment of danger is strong, it's not possible to entrust this object with one's life without feeling some uneasiness: "It's not reliable, it's only plastic."

Prevention strategies centered on condoms are common, but they can have several shortcomings relative to emblematic rationality. As the above cases demonstrated, this management is not necessarily grounded in accurate knowledge, a just and measured vision of risk, nor is it without contradictions. It can also operate in obscurity or in panic. When risk is exaggerated, the need for protection can appear highly imperative to some.

\section{- Social Protection}

When one's social milieu is reassuring, staying within it preserves one from danger. First of all, this dictates avoiding any possible relationship with someone who is HIV-positive (MatickaTyndale, 1992), which could only happen in unusual situations. Avoidance constitutes one dimension of the sexual restriction that characterizes these strategies: avoiding encounters in certain places (especially bars and night clubs), in certain circumstances where social control is diminished, with certain categories of people (essentially drug addicts, bisexuals, those who have sex with several partners, and prostitutes), who are considered dangerous. Categorizing people and places is a way of separating the familiar, known, normal, reassuring, and worthy of confidence from the worrisome, foreign, strange, and abnormal.

Twenty-year-old Terence, who is from a privileged background, categorically refuses to use a condom. “I don't like having sex under cellophane, and I prefer to abstain from sex with someone whom I consider to be at risk." $\mathrm{He}$ is comforted by the fact that he only frequents a "milieu" that he "knows," has "traditional associations" with people he's "known since kindergarten... in the same circle," in which he feels integrated, supported, and reas- sured. He never goes alone to such places of perdition as night clubs. Given "the slightest doubt," he would abstain and "take his distance" because "there is no point in making love" under such conditions; he could not enjoy it. For him, as for many others, the necessity of prevention is limited to those who have sex with large numbers of different partners. In addition, he thinks he can trust appearances: "The way someone looks gives you a good idea of the people they frequent." On the other hand, paradoxically, simply enjoying a relationship with someone makes any kind of precaution unnecessary. "If you're with someone you like, with whom you want to spend time and make love, that means you trust her."

Avoidance strategies, where condom use is denigrated and rejected, are common among people who do not have a stable partner, often have considerable social and cultural capital, and think they can control risk with strategies that are far from justifying their feeling of security and certainty.

\section{- Dependence and bricolage: women and control}

While preventive recommendations often suggest that condom use be discussed and negotiated before a sexual act, it is not always possible to act on this advice. In fact, men and women find themselves in a situation of unequal control regarding condoms (Holland et al., 1990; Kippax, et al., 1990; Krieger \& Margo, 1990; Carovano, 1991; Waldby et al., 1993; Campbell, 1995). Men can al ways use one without having to ask their partner, but if they do not bring it up, women have to ask for and sometimes demand it. Based on our interviews, negotiation is sometimes conflictual and difficult, and women may legitimize condom use by arguing that it serves to prevent pregnancy. One option is to present the choice of either a sexual act with a condom or no sexual act at all. It is easier to exert such pressure in the context of an infrequent encounter. Young, desirable women, who would have no difficulty replacing an obstinate partner, are most convincing. Middle-aged women are less convincing and more dependent on male choices. This is even more the case for women from less privileged social classes. They can not always adopt a stable line of conduct regarding condoms. In these cases of dependent and makeshift strategies, the feeling of vulnerability is high and risk is perceived as difficult to master. Actions are dependent on the partner and the margin of negotiation is reduced. 
For Thérèse, a 38-year-old single secretary who considers herself "the epitome of the noninformed," danger is both omnipresent and uncontrollable. AIDS is a real "threat," a "concern," because she knows that she has taken risks in her "very di spersed" sex life. She does not have the comfort of "the confidence of a stable relationship." "We can know what precautions we should take, but that doesn't mean we can act on them. Things don't al ways work out without a hitch." She says she usually has condoms on her, but that "sometimes things happen too fast," and she does not always "pay attention." What bothers her most is that one has to use them "in the very beginning," during the uncertain and undetermined moment of amorous conquest. Desire is thwarted when calculation and planning take over that which one would like to consi der unpredictable or improvised. "It's definitely true that just being ready to anticipate in that way makes you less into it... You have to think about those kinds of things calmly, but that almost leads you to renounce altogether." In addition, condoms "limit the romp," particularly fellatio: "if it's with a condom, I won't do it." Since the test has to be "performed again every day," the only "remedy" would be fidelity, but that is not adapted to her sexual activity, because she is not part of "a stable couple." "We're al ways ready to do without condoms," she says, reversing a common slogan. She hates to have to demand them sometimes, which leads her to consider that her lovers do not practice prevention and that they "could get stuff and then transmit it." For her, danger is everywhere, among her probably imprudent lovers, in different contacts and diverse practices. She tries to hang on to categorization that proves not to be very reassuring: "as long as someone isn't a junkie or a homosexual,you think that he's already less at risk, but that's not true." Since her lovers would only say "what they want to say," so that she can not trust them, she thinks she has to "do all she can" use condoms or abstain - but does not really do this. "In fact, the whole thing for me boils down to this: abstain or takethe risk."

Another example of dependent feminine strategies involves women who are involved in serious relationships, doubt their partner's fidelity, but refuse to jeopardize their relationships by addressing the question directly. Note that more women doubt the fidelity of their partner than men, who tend to feel extremely protected when they are involved in serious relationships. Thus, 20-year-old Corrine drags her companion to give blood so as to assure herself of his serological status. Julie, a 38-year- old designer, is loyal to her apparently fickle companion. Because of this, she protects the familial peace by regularly verifying her own serological status.

\section{Conclusion}

It is the combination of three forms of risk perception - catastrophe, bodily threat, and social threat - that allows for the comprehension of actions and their diversity, accounting for the effect of how much control people feel they exercise over themselves, others, and the world. That which is controllable is obviously linked to that which is predictable. Prevention therefore relies on a dynamic of empowerment, which does not only occur by integrating information but also by being able to discern a controllable risk and managing it to the best of one's ability. The model presented here stresses context so as to allow for the articulation of risk perception and action. On the level of sociocognitive processes, it suggests a complex perception of risk that is developed on several registers. It builds on notions from earlier models - vulnerability, control, self efficacy - but, by drawing on concepts and findings from social psychology, sociology, and anthropology, it provides a broader interpretation than one that is purely individualistic. Finally, it considers the links between risk perception and action, not in a linear perspective - from cognition to action, but in an interactive perspective. Action, while dependent on processes of interpretation, engenders ways of perceiving risk and orienting feelings of vulnerability by enacting the possibility or impossibility of mastery. 
Acknowledgments

This research was funded by the Agence Nationale de Recherche sur leSida (A.N.R.S.) of France. Thanks to Abigail Cope Saguy for the translation of this article.

\section{References}

ARMSTRONG, D., 1993. Public health spaces and the fabrication of identity. Sociology, 27:393-410.

BLOOR, M., 1995a. TheSociology of HIV Transmission. London: Sage.

BLOOR, M., 1995b. A user's guide to contrasting theories of HIV-related risk behaviour. In: Medicine, Health and Risk (J. Gabe, ed.), pp. 19-30, Oxford/Cambridge: Blackwell Publishers.

BLOOR, M.; McKEGANEY, N.; FINLAY, A. \& BARNARD, M., 1992. The inappropriateness of psycho-social models of risk behaviour to understanding HIVrelated risk behaviour among Glasgow male prostitutes. AIDS Care, 4:131-137.

BANDURA, A., 1992. A social cognitive approach of the exercise of control over AIDS infection. In: Adolescents and AIDS: A Generation in Jeopardy (R. J. Di Clemente, ed.), pp. 86-116, London: Sage.

CAM PBELL, C. A., 1995. M al e gender roles and sexuality: Implications for women's AIDS risk and prevention. Social Science and Medicine, 41:197-210.

CAROVANO, K., 1991. More than mothers and whores: Redefining the AIDS prevention needs of women. International Journal of Health Services, 21:131142.

CRAWFORD, R., 1994. The boundaries of the self and the unhealthy other: Reflections on health, culture and AIDS. Social Science and Medicine, 38: 1347-1365.

DOU GLAS, M., 1996. Purity and Danger: An Analysis of the Concept of Pollution and Taboo. Harmondsworth/Middlesex: Penguin Books.

DOUGLAS, M., 1992. Risk and Blame: Essaysin Cultural Theories. London/New York: Routledge.

DOUGLAS, M \& \& CALVEZ, M., 1990. The self as risktaker: A cultural theory of contagion in relation to AIDS. Sociological Review, 38:445-464.

DOU GLAS, M. \&WILDAVSKY, A., 1982. Risk and Culture. Berkeley/ Los Angeles: University of California Press.

FEE, E. \& KRIEGER, N., 1993. Understanding AIDS: Historical interpretations and the limits of biomedical individualism. American Journal of Public Health, 10:1477-1486.

FISHBEIN, M. \& AJZEN, I., 1975. Belief, Attitude, Intention and Behavior: An Introduction to Theory and Research. Reading: Addison-Wesley.

GABE, J., 1995. Health, medicine and risk: The need for a sociological approach. In: Medicine, Health and Risk (J. Gabe, ed.), pp. 1-18, Oxford/Cambridge: Blackwell Publishers.

GRECO, M., 1993. Psychosomatic subjects and the "duty of the will": Personal agency within medical rationality. Economy and Society, 22:357-372.
HAYES, M. V., 1992. On the epistemology of risk: Language, logic and social science. Social Scienceand Medicine, 35:401-407.

HIV/AIDS SURVEILLANCE IN EUROPE, 1996. Quarterly Report, 61:3.

HOGGART, R., 1957. The Uses of Literacy. London: Chatto \& Windus.

HOLLAND, J.; ROM AZANOGLU, C.; SCOTT, S.; SHARPE, S. \&THOMSON, R., 1990. Sex, gender and power: Young women's sexuality in the shadow of AIDS. Sociology of Health and IIIness, 12: 336-350.

HERZLICH, C., 1969. Santé et Maladie. Analysed'une Représéntation Sociale. Paris: Mouton.

JEFFERY, R. W., 1989. Risk behaviors and health: Contrasting individual and population perspectives. American Psychologist, 44:1194-1202.

KIPPAX, S.; CRAWFORD, J.; WALDBY, C. \& BENTON, P., 1990. Women negociating heterosex: Implications for HIV prevention. Women's Studies International Forum, 13:533-542.

KRIEGER, N. \& MARGO, G. ,1990. Women and AIDS: Introduction to "Section on AIDS: The politics of survival". International Journal of Health Services, 20:583-588.

LUPTON, D., 1993. Risk as moral danger: The social and political functions of risk discourse in public health. International Journal of Health Services, 23:425-435.

LUPTON, D., 1995. The Imperative of Health; Public Heal th and the Regulated Body. London: Sage.

MATICKA-TYNDALE, E., 1992. Social construction of HIV transmission and prevention among heterosexual adults. Social Problems, 39:238-252.

MISHLER, E. G., 1986. Research Interviewing:Context and Narrative. Cambridge: Harvard University Press.

O'BRIEN, B. J., 1989. AIDS and subjective risk assessment: A critical review. Health Policy, 13:213-224.

PAICHELER, G., 1994. Le Public Face à la Menace du Sida. Vol. I: Interprétation des Connaissances et Prise de Conscience du Risque. Paris: Agence Nationale de Recherche sur leSida.

PAICHELER, G., 1996. Le Public Face à la Menace du Sida. Vol. II: Gérer le Risque. Paris: Agence Nationale de Recherche sur le Sida.

PAICHELER, G. \& QUEMIN, A., 1994a. Actions de prévention du Sida et public: Prolégomènes à la réception et à l'interprétation des discours de communication de masse. Discours Social/Social Discours, 3-4:47-67.

PAICHELER, G. \& QUEMIN, A., 1994b. Une intolerance diffuse: Les rumeurs sur I'origine du Sida. Sciences Social es et Santé, 12:41-72. 
PARSONS, E. \& ATKINSON, P., 1992. Lay construction of genetic risk. Sociology of Health and IIIness, 14:437-455.

PERUGA, A. \& CELENTANO, D. D., 1993. Correlates of AIDS knowledge in samples of the general population. Social Science and Medicine, 36:509-524.

POLKINHORNE, D. E., 1988. NarrativeKnowing and the Human Sciences. Albany: State University of New York Press.

ROSENSTOCK, I. M., 1974. The Health Belief Model and preventive health behavior. Health Education Monographs, 2: 354-386.

ROZIN, P. \& FALLON, A., 1987. A perspective on disgust. Psychological Review, 94:23-41.

ROZIN, P.; MARKWITH, M. \& NEMEROFF, C., 1992. Moral contagion and fear of AIDS. Journal of Applied Social Psychology, 22:1081-1092.

SARBIN, T. R., 1986. The Storied Nature of Human Conduct. New York: Preager.
SCHILLER, N. G., CRYSTAL, S. \& LEWELLEN, D., 1994. Risky business: The cultural construction of AIDS risk groups. Social Science and Medicine, 38: 1337-1346.

SCHILTZ, M. A. \& ADAM, P., 1995. Les Homosexuels Face au Sida: Enquête 1993 sur les Modes deVie et les Gestions du Risque. Paris: Agence Nationale de Recherche sur le Sida.

SONTAG, S., 1978. IIIness as Metaphor. London: Penguin Books.

TVERSKY, A. \& KAHNEM AN, D., 1974. Judgment under uncertainty: Heuristics and biases. Science, 185:1124-1131.

WALDBY, C.; KIPPAX, S. \& CRAWFORD, J., 1993. Research note: Heterosexual men and "safe sex" practice. Sociology of Health and IIIness, 15:246-256.

WARWICK, I.; AGGLETON, P. \& HOM ANS, H., 1988. Constructing commonsense - Young people's beliefs about AIDS. Sociology of Health and IIIness, 10:213-233. 